ISSN: 1907-9931 (print), 2476-9991 (online)

\title{
STUDY OF NUTRITIONAL CONTENTS OF SEA URCHIN GONAD FROM DRINI BEACH, GUNUNG KIDUL, YOGYAKARTA
}

\author{
Delianis Pringgenies, Ali Ridlo*, Richardus Mahatmada Indrajati and Ali Djunaedi \\ Department of Marine Science, Diponegoro University, Semarang, Indonesia \\ *Corresponden author email: delianispringgenies@lecturer.undip.ac.id \\ Submitted: 05 July 2020 / Revised: 04 December 2020 / Accepted: 17 December 2020
}

http://doi.org/10.21107/jk.v13i3.7808

\begin{abstract}
This paper aims to determine the types and contents of protein, fatty acids, amino acids and protein in the gonads of Arbacia lixula, Colobocentrotus atratus, Heterocentrotus trigonarius and Echinotrix diadema from the waters of Drini, Gunung Kidul, Yogyakarta. Kjedal method was used to analyze the protein content, while GC and HPLC methods were employed to analyze amino acids in this study. The results showed that the protein contents of each sample, consequently from highest to lowest, were Heterocentrotus trigonarius (13.3\%), Echinotrix diadema (10.86), Colobocentrotus atratus (10.41) and Arbacia lixula (9.90\%). Amino acids analysis from all identified both saturated fatty acids, consisting of lauric acid, myristic acid, palmitic acid, stearic acid, arachidonic acid, lignoceric acid, as well as non-saturated fatty acids, consisting of palmitoleic acid, oleic acid, linoleic acid, erucic acid, EPA, and DHA. The highest contents of non-saturated fatty acids were identified in Colobocentrotus atratus (434.14 mg/100g) and the lowest content in Arbacia lixula (197.71 mg/100g). The highest percentage of essential fatty acids was found in Heterocentrotus trigonarius (0.29\%), whereas the lowest was found in Echinotrix diadema (0.19\%). It is concluded that the gonad of Heterocentrotus trigonarius showed the highest protein and essential fatty acids contents. This study also found that Colobocentrotus atratus sea urchin gonads possess the highest content of non-saturated fatty acids (434.14 mg/100g).
\end{abstract}

Keywords: amino acid, fatty acid, protein, sea urchin gonad.

\section{INTRODUCTION}

Protein is a vital nutrition for human body functions since it is the most significant substance in many biological processes. It is the building block in the formation of new tissues during development phase, and during the process of maintaining, repairing, and replacing damaged tissues. Protein is also stored and converted in the body as an energy reserve in the event of fat and carbohydrate deficiency. Through biochemical reactions, excess protein is converted into fat and stored as fat reserve (Sumardjo, 2008).

Life in Earth thrives by the availability of many natural media, namely air, land and sea. Marine life is a complex structure with vast biological pattern, chemistry and material diversity. This puts sea not only as a source of food, but also as a repository of materials which are precious, special, and impactful for humanity. Recent studies found potency of various marine resources as biomaterials with a plethora of application in the field of medicine (Talumepa et al., 2016). One of such marine lives with potential medicinal properties is sea urchin (Pringgenies et al., 2012).

Sea urchin is commonly found in coastal areas and waters of Indonesia, and many other places in the world. The test or shell of this marine animal is commonly covered with venomous spines that the common people often think trivially of sea urchins. Upon bisection of a sea urchin, eggs or gonads appears to be the dominant organ, which is known to have high nutritional value. For example, gonad of Diadema setosum species has been known to possess high amount of essential nutrition which is needed by the body. As with any animals, different sea urchin species may contain different nutritional value. Therefore, this study aims to determine the contents of protein, amino acids, and fatty acids of sea urchins from the species Arbacia 
lixula, Colobocentrotus atratus, Heterocentrotus trigonarius and Echinotrix diadema from the waters of Drini, Gunung Kidul, Yogyakarta.

\section{MATERIALS AND METHODS Sea Urchin Sample Collection}

Samples of live sea urchins consiting of Arbacia lixula, Colobocentrotus atratus, Heterocentrotus trigonarius and Echinotrix diademawere collected using a small scoop from waters of Drini, Gunung Kidul, Yogyakarta. Each sample was bisected from mouth to anus with a knife, followed by collection of gonad using a small spoon. The gonad of each sample was put into a glass vial using a glass funnel. The samples were then divided into ratio, with 5 grams for $10 \mathrm{cc}$ vial and 50 grams for $50 \mathrm{cc}$ vial. The contained samples were then stored in a freezer to avoid deterioration.

\section{Analysis of Protein, Amino Acids and Fatty Acids Contents}

Analysis of protein contents in this study employed Micro method (AOAC, 1970) and Gas Chromatography (GC) and HighPerformance Liquid Chromatography (HPLC) were used to analyze amino acids and fatty acids contents in the samples.

\section{Protein Contents \\ RESULTS AND DISCUSSION}

The analysis of protein contents of sea urchin gonad was performed in accordance to methods in Kejdahl. Analysis results found that the highest percentage of protein content was in $H$. trigonarius (10.41) and the lowest percentage was in A. lixula (9.90), as presented in Image 1 below.

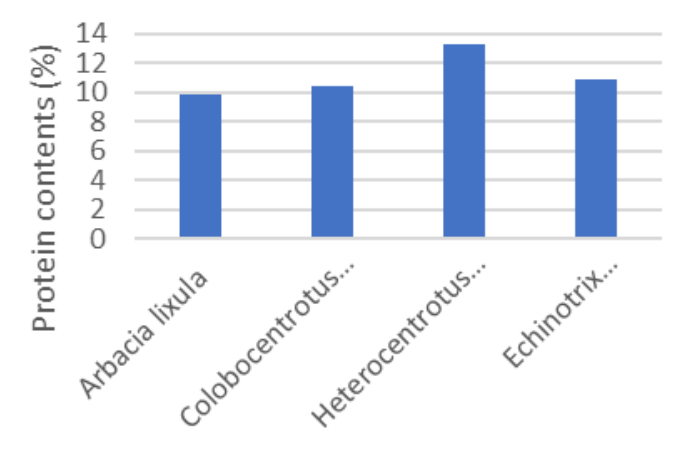

Figure 1. Protein contents of sea urchins species studied in this research.

\section{Amino Acids Contents}

Amino acids analysis by High-Performance Liquid Chromatography (HPLC) using a Shimadzu LC10A found 15 amino acids. The complete results are presented in Table 1 and Image 2. Analysis result of the species A. lixula found 15 amino acids contents, in which details were 9 essential amino acids (histidine, isoleucine, lysine, valine, methionine, threonine, phenylalanine, and arginine) and 6 non-essential amino acids (glutamate, alanine, tyrosine, serine, aspartate, and glycine). The highest content of non-essential amino acids found in $\mathrm{H}$. trigonarius and $\mathrm{E}$. diadema was aspartic acid, $0.19 \%$. The highest glutamate content, $1.39 \%$, was found in E. diadema. The essential amino acids contents in all the species studied were found to be low on average. The highest content was found in $\mathrm{E}$. diadema, namely arginine $0.09 \%$. The total amino acids contents of each sea urchin species from the highest to the lowest were $0.37 \%, 0.35 \%, 0.32 \%$, and $0.24 \%$ for $E$. diadema, $\mathrm{H}$. trigonarius, $\mathrm{A}$. lixula, and $\mathrm{C}$. atratus respectively.

Table 1. Amino acid contents of sea urchin gonad.

\begin{tabular}{|c|c|c|c|c|c|}
\hline \multirow{2}{*}{ No } & \multirow{2}{*}{ Amino Acid } & \multicolumn{4}{|c|}{ Amino acid content (\%) } \\
\hline & & A. lixula & C. atratus & H. trigonarius & E. diadema \\
\hline \multicolumn{6}{|c|}{ Essential Amino Acids } \\
\hline 1. & Histidine & 0.01 & 0.01 & 0.01 & 0.01 \\
\hline 2. & Isoleucine & 0.04 & - & 0.04 & 0.04 \\
\hline 3. & Leucine & 0.05 & 0.04 & 0.05 & 0.06 \\
\hline \multirow{3}{*}{$\begin{array}{l}4 . \\
5 . \\
6 .\end{array}$} & \multirow{3}{*}{$\begin{array}{l}\text { Lysine } \\
\text { Valine } \\
\text { Methionine }\end{array}$} & 0.01 & 0.01 & - & 0.01 \\
\hline & & 0.05 & - & 0.05 & 0.06 \\
\hline & & 0.01 & - & - & - \\
\hline \multirow{2}{*}{$\begin{array}{l}7 . \\
8 .\end{array}$} & \multirow{2}{*}{$\begin{array}{l}\text { Threonine } \\
\text { Phenylalanine }\end{array}$} & 0.07 & 0.07 & \multirow{2}{*}{$\begin{array}{l}0.07 \\
0.02\end{array}$} & \multirow{2}{*}{$\begin{array}{l}0.07 \\
0.03\end{array}$} \\
\hline & & 0.02 & 0.05 & & \\
\hline 9. & Arginine & 0.06 & 0.06 & 0.11 & 0.09 \\
\hline
\end{tabular}


Pringgenies et al., Study Of Nutritional Content Of Sea Urchin

\begin{tabular}{rlllll}
\hline & Total essential am. & 0.32 & 0.24 & 0.35 & 0.37 \\
\hline & acd & Non-essential Amino Acids & & \\
10. & Glutamate & 0.13 & 0.14 & 0.14 & 0.39 \\
11. & Alanine & 0.09 & 0.12 & 0.11 & 0.04 \\
12. & Tyrosine & 0.03 & 0.03 & 0.03 & 0.07 \\
13. & Serine & 0.07 & 0.07 & 0.08 & 0.19 \\
14. & Aspartate & 0.17 & 0.17 & 0.19 & 0.11 \\
15. & Glycine & 0.15 & 0.14 & 0.12 & \\
\hline
\end{tabular}
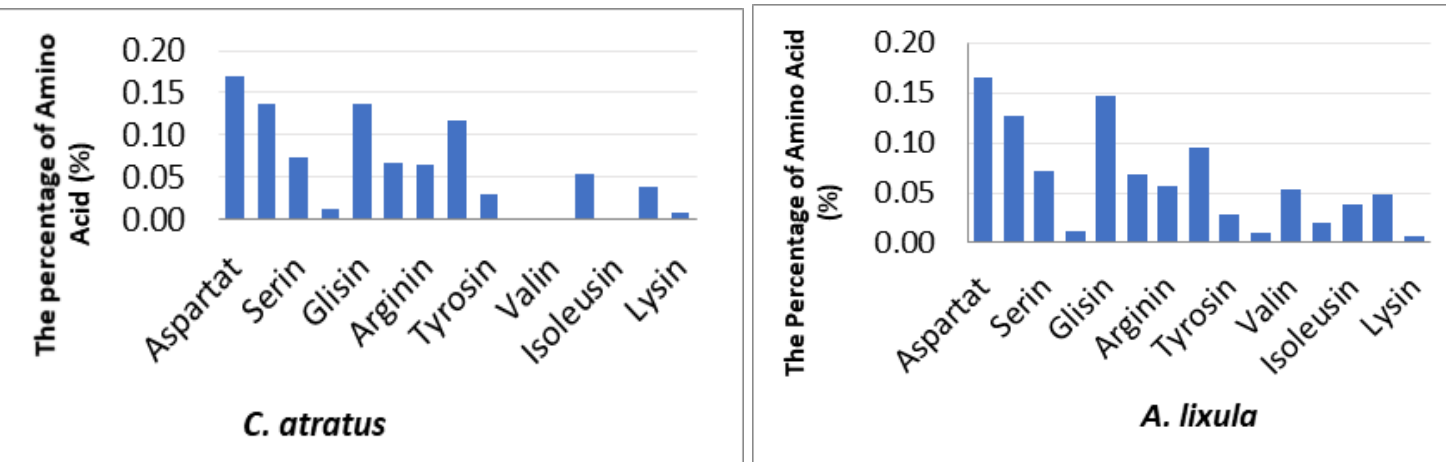

A. lixula

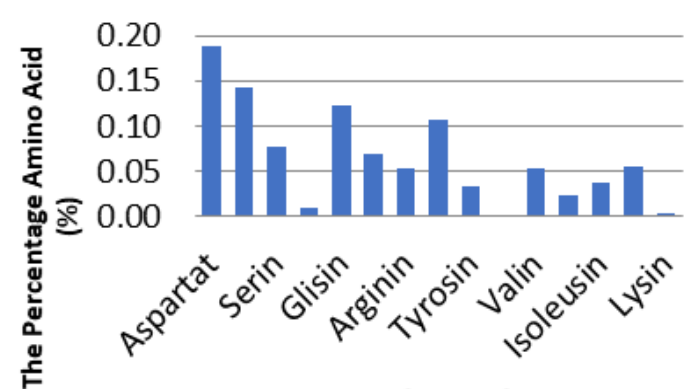

H. trigonarius

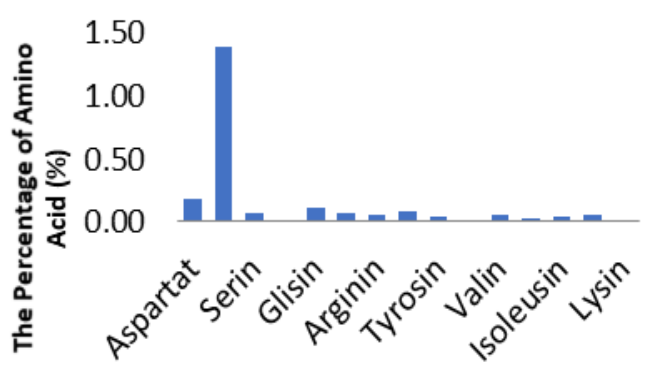

E. Diadema

Figure 2. Composition of fatty acids in C. Atratus (a), A. Lixula (b), H. trigonarius, and E. diadema.

Fatty Acids Acids Contents

The fatty acids contents analysis in sea urchin gonads were performed using Gas
Chromatography. The complete analysis results are presented in Table 2 below.

Table 2. Fatty acids contents of A. Lixula and C. Atratus

\begin{tabular}{|c|c|c|c|c|c|c|}
\hline \multirow[b]{2}{*}{ No } & \multirow[b]{2}{*}{ Fatty Acids } & \multicolumn{5}{|c|}{ Contents (mg/100g) } \\
\hline & & & $\begin{array}{c}\text { A. } \\
\text { lixula }\end{array}$ & $\begin{array}{c}\text { C. } \\
\text { atratus }\end{array}$ & $\begin{array}{c}H . \\
\text { trigonarius }\end{array}$ & E. diadema \\
\hline \multicolumn{7}{|c|}{ Saturated } \\
\hline 1. & Lauric Acid & C12:0 & 1.00 & 0.60 & - & - \\
\hline 2. & Myristic Acid & $\mathrm{C} 14: 0$ & 72.86 & 35.76 & 162.57 & 186.67 \\
\hline 3. & Palmitic Acid & C16:0 & 161.18 & 230.48 & 253.73 & 505.51 \\
\hline 4. & Stearic Acid & C18:0 & 29.57 & 43.71 & 65 & 112 \\
\hline 5. & $\begin{array}{l}\text { Archidonic Acid } \\
(\omega 6)\end{array}$ & C20:0 & 5.68 & 2.78 & 82.92 & 113.5 \\
\hline \multirow[t]{2}{*}{6.} & Lignoceric Acid & $\mathrm{C} 24: 0$ & 2.15 & 2.78 & - & - \\
\hline & $\begin{array}{l}\text { Total Saturated } \\
\text { Fatty Acids }\end{array}$ & & 272.44 & 316.11 & 564.22 & 917.68 \\
\hline
\end{tabular}


Monounsaturated

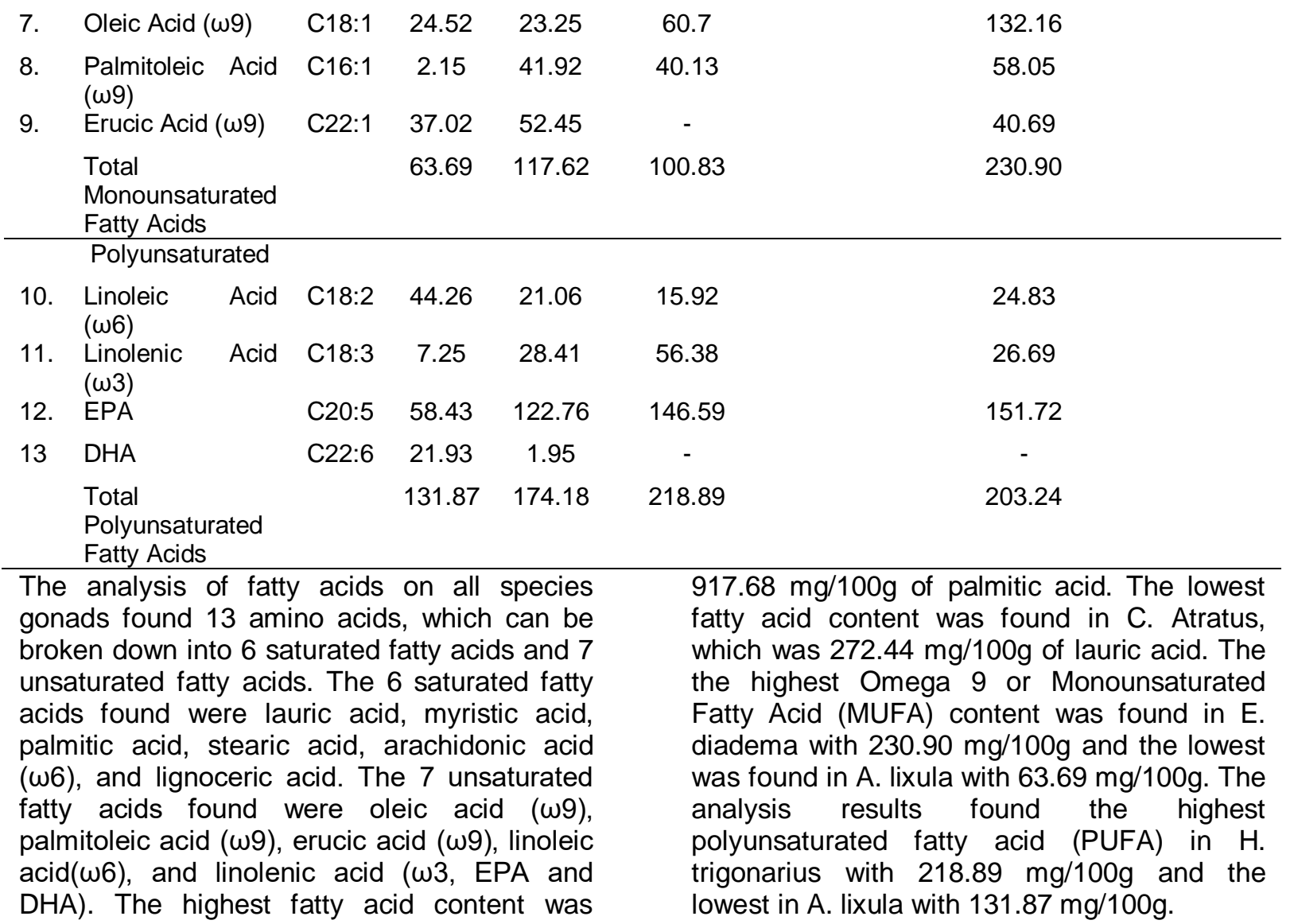
found in the species E. diadema, which was
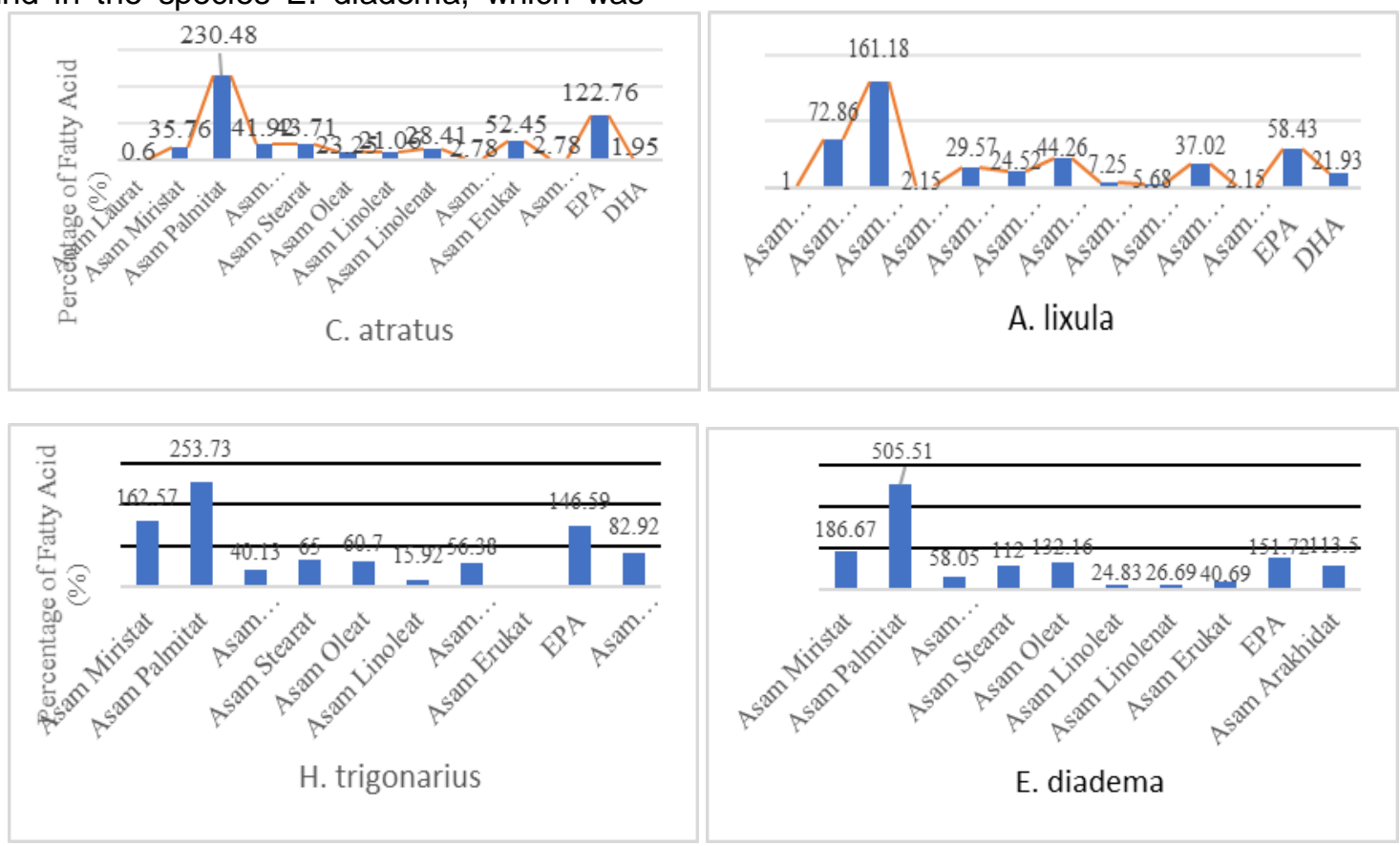

Figure 3. Fatty acids composition in $\mathrm{C}$. atratus (a) and A. lixula (b) $\mathrm{H}$. Trigonarius and $\mathrm{E}$. diadema.
The analysis found that the highest overall protein content belonged to the species $\mathrm{H}$. Trigonarius, with $13.3 \%$, and the lowest belonged to the species A. Lixula, with $9.90 \%$. The variation in the protein contents is highly 
related to the availability of food in the natural habitat of the sea urchins. $\mathrm{H}$. Trigonarius is commonly found in areas with more algae population and which is far away from human activities. On the contrary, A. Lixula is commonly lives in sites often used as snorkeling, in which algae population is often diminshed do to use of snorkeling fins. According to Suryanti and Ruswahyuni (2014), among the environmental condition affecting the protein contents of sea urchins is the growth of algae, since algae is the main diet of the this herbivorous species.

The protein contents of $\mathrm{H}$. trigonarius (13.3\%) was found to be higher than that of D. setosum from the waters of Martafons (12.80\%), yet the protein contents of D. setosum from Sopapei waters was still the highest $(17.69 \%)$ of all the sea urchin species above (Upan and Silaban, 2017). However, the lowest protein content was also found in the waters of Waai, which was $5.40 \%$. These findings confirms the theory that the same species may have different protein contents in different environment. The varying nutrition contents is significantly related to habitat, as pointed out by Arifudin et al., (2014) which stated that species, age, size and habitat conditions can affect the nutrition content of an animal produce.

Based on the analysis results in this study, the protein contents in gonads of Arbacia lixula $(9.90 \%)$, C. atratus $(10.40 \%), \mathrm{H}$. trigonarius $(13.3 \%)$ and E. diadema $(10.86 \%)$ were significantly higher to the protein contents found in poultry eggs. A study by Bakhtra et al (2016) on the protein contents of broiler chicken, local chicken, duck egg and quail egg found all to be no higher than $7 \%$.

The protein contents of both sea urchin species analyzed in this study are still within the normal macro distribution of nurtrition intake, which is between $9.90-13.3 \%$. These levels are adequate protein requirements for growth and devlopment of infants. According to Hardinsyah et al. (2016), the macro nutrition distribution range from the diet pattern of Indonesian people based on the analysis of Basic Medical Research (Riskedas) 2010 is 9$14 \%$ of protein energy. Macro Nutrition Enegy Range Recommendation (AMDR) for Indonesians in the estimation of ideal nutrition intake is $5-15 \%$ protein energy, depending on age or developmental stages. The percentage of protein enegy for $0-5$ years of age is $9.4 \%$.
The analysis of amino acids contents of all the species in this research found that they were below that of D. Setosum gonad, which was studied by Pringgenies et al., (2016). The complete data showed Aspartate 11.6\%; Glutamate $15.2 \%$; Serine $5.9 \%$; Histidine 2.4\%; Glycine 3.3\%; Threonine 5.5\%; Arginine $8.5 \%$; Alanine $8.3 \%$; Tyrosine $4.9 \%$; Methionine 3.3\%; Valine 5.9\%; Phenylalanine $5.6 \%$; Isoleucine 5.0\%; Leucine 9.1\%; Lysine $4.3 \%$ Tryptophan $0.8 \%$. The tryptophan content in D. setosum was not found in all species in this study. Methionine and valine contents were only found on A. lixula but not in the gonad of the other three species in this study. Isoleucin was not found un the gonad of C. atratus and lysine was not found in the gonad of $\mathrm{H}$. trigonarius. This meant that the amino acid contents of sea urchins are also affected by the habitat in which they live.

The analysis of gonad of A. lixula showed 15 amino acids which consist of 9 essential and 6 non-essential amino acids. The essential amino acids found un the gonad of this species include arginine, histidine, isoleucine, leucine, lysine, valine, methionine, threonine and phenylalanine. The non-essential amino acids found in A. lixula gonad were Glutamate, alanine, tyrosine, serine, aspartate, dan glycine. Of the four species gonad studied, A. lixula gonad had the most amino acids variety. The amino acids content in A. lixula gonad is sufficient for the nutritional requirements of adults and children. However, this study also found that the amino acids content of $\mathrm{C}$. atratus does not completely meet the required variety for ideal nutrition. According to Purwaningsih et al., (2013), essential amino acids for adults include lysine, isoleucine, threonine, methionine, valine, phenylalanine, and tryptophan, whereas children needs the addition of arginine and histidine. Nonessential amino acids consist of aspartate, glutamate, alanine, asparigine, cysteine, glycine, proline, tyrosine, serine and glutamine.

Of all the non-essential amino acids, aspartic acid was found to be the highest content with $0.17 \%-0.19 \%$, resulting in more better taste organoleptic stimulation. This reinforces the findings in Rahayu et al., (2014) which states that aspartic acid is the most vital component in construction of taste perception, which stimulates the gustatoric organs. The lowest lysine contents was found in A. lixula, C. atratus and $\mathrm{E}$. diadema, and was not detected in $\mathrm{H}$. trigonarius. This means the gonads of all 
Jurnal Kelautan, 13(3), 219-227 (2020)

four sea urchin species are not the most effective materials to strengthen antiboy. However, two species with the most lysine contents can still be used in nutrition source for growth. Lysine plays an imporant role as the basic building block of blood antibody, improving circulatory system, and maintaining the growth of normal cells. Together with proline and vitamin $\mathrm{C}$, lysine forms colagen and helps in lowering excessive blood triglycerides. Lysine deficiency may lead to lower endurance, difficulty in concentrating, hairfall, anemia, arrested growth, and reproduction system disruption (Purwaningsih et al., 2013). Methionine was only found in A. lixula in this study. Methionine possesses sulfur bond which is sensitive of oxidation and breaks down during acid hydrolisis. According to Ginting et al., (2017), amino acids with sulfur bond, such as methionine and cysteine, breaks down during acid hydrolisis, requiring prior oxidation of samples using performic acid to oxidize methionine bond into methionine solfon bond, before being hydrolized with $\mathrm{H} 2 \mathrm{SO} 46 \mathrm{~N}$.

Analysis of fatty acid contents in the gonads of all species in this study revealed that they were higher than that found in D. setosum in a study by Pringgenies et al. (2016). However, the fatty acid contents of $D$. setosum in the same study is higher than that of A. lixula dan C. Atratus in this research. This difference in nutritional contents is due to difference in species, environmental conditions, size of species and gonad maturity, which coonfirms the finding of similar study bu Azka et al., (2015). Fat is an excess reserved by animals, which means that the fat content in a species is highly determined by the energy balance of the said species. Purwaningsih (2012) found that the fat content of a species can be influenced by gonad maturity and the age of a species. The more mature the gonad of a species, the more fat contents it will have.

Fatty acid analysis of gonads from the species A. lixula, C. atratus, $H$. trigonarius and $E$. Diadema found omega-3, omega-6, and omega-9 with omega-3 to omega- 6 ratio of $3: 1$. This means the gonads of all species studied in this research is safe for consumption. Silaban and Srimarina (2013) stated that acceptable fatty acid ratio of omega-3 to omega- 6 is below 1:5. If omega- 6 upsets omega- 3 in the ratio, it will give negative impacts towards cognition, mood, and behavior. The recommended omega- 6 to omega-3 consumption ratio is $4: 1$, which is ideal to maintain health, particularly in preventing cardiovascular disease. Those affected by cardiovascular disease are recommended to have in intake of omega- 6 and omega-3 with 1:1 ratio. The highest unsaturated fatty acids in this study was found in the gonad of C.atratus (434.14 mg/100g) and the lowest in the gonad of A. lixula (197.71 $\mathrm{mg} / 100 \mathrm{~g}$ ).

In addtion, analysis of Eicosapentaenoic acid (EPA) contents found the highest in the gonad of $E$. diadema, followed subsequently by $\mathrm{H}$. trigonarius, C. atratus and A. lixula. Analysis of Docosahexaenoic acid (DHA) contents only found the fatty acids in the gonads of A. Lixula and C. Atratus. EPA and DHA are vital in the brain development as well as in body immune system. Omega 3-PUFA, EPA, and DHA have potency in preventing cardiovascular disease, improving brain capacity and strenthening the immune system (Jacoeb et al., 2014). Diana (2012) also stated similar findings that unsaturated fatty acid is dominant in the brain nervous cell system. It is also known that $60 \%$ of human brain consists of various fats, including unsaturated fatty acids namely omega 3, EPA, DHA, omega 6, AA, and omega 9. Essential fatty acids is also an important intake during the brain and physical growth and development period of foetus, infants and children (Pringgenies et al, 2016).

\section{CONCLUSIONS AND SUGGESTIONS}

The gonad of Heterocentrotus trigonarius showed the highest protein contents (10.41\%) whereas the gonad of Arbacia lixula showed the lowest content (9.90\%). The highest fatty acid contents was found in the gonad of Echinotrix diadema, with $917.68 \mathrm{mg} / 100 \mathrm{~g}$ palmitic acid, whereas the lowest was found in Colobocentrus atratus with $272.44 \mathrm{mg} / 100 \mathrm{~g}$ lauric acid. The highest omega 9 (MUFA) was found in the gonad of Echinotrix diadema $(230.90 \mathrm{mg} / 100 \mathrm{~g})$ and the lowest was found in the gonad of Arbacia lixula (63.69 mg/100g). The highest PUFA content was found in the gonad of Heterocentrotus trigonarius (218.89 $\mathrm{mg} / 100 \mathrm{~g}$ ) and the lowest was found in the gonad of Arbacia lixula (131.87 mg/100g).

\section{REFERENCES}

Afifudin, I. K., Suseno, S. H., \& Jacoeb, A. M. (2014). Profil asam lemak dan asam amino gonad bulu babi. Jurnal Pengolahan Hasil Perikanan Indonesia, 17(1), 60-70. 
Akerina, F. O., Nurhayati, T., \& Suwandy, R. (2015). Isolasi dan Karakterisasi Senyawa Antibakteri dari Bulu Babi. Jurnal Pengolahan Hasil Perikanan Indonesia, 18(1), 61-73.

Anastasia, Y. (2011). Teknik Analisis Residu Golongan Tetrasiklin dalam Daging Ayam secara Kromatografi Cair Kinerja Tinggi. Buletin Teknik Pertanian, 16(2), 68-73.

AOAC. (1970). Official Methods of Analysis of The Association of Official Analytical Chemists . Washington, D.C.

Aprilia, H. A., Pringgenies, D., \& Yudiati, E. (2012). Uji toksisitas ekstrak kloroform cangkang dan duri landak laut (Diadema setosum) terhadap mortalitas Nauplius Artemia sp. Journal of Marine Research, $1(1), 75-83$.

Ardianingsih, R. (2009). Penggunaan High Performance Liquid Chromatography (HPLC) dalam Proses Analisa Deteksi Ion. Berita Dirgantara, 10(4), 101-104.

Aziz, A. (1993). Beberapa catatan tentang perikanan bulu babi. Oseana, 18(2), 6575.

Azka, A., \& Nurjanah, J. A. (2015). Profil asam lemak, asam amino, total karotenoid, dan a-tokoferol telur ikan terbang. Jurnal Pengolahan Hasil Perikanan Indonesia, 18(3), 250-261.

Bakhtra, D. D. A., Rusdi, R., \& Mardiah, A. (2017). Penetapan Kadar Protein Dalam Telur Unggas Melalui Analisis Nitrogen Menggunakan Metode Kjeldahl. Jurnal Farmasi Higea, 8(2), 143-150.

Bintang, M. (2010). Biokimia Teknik Penelitian. Erlangga, Jakarta. Hal : 99, 103-106.

Darsono, P. (1986). Gonad bulu babi. Oseana, 11(4), 151-162.

Diana, F. M. (2012). OMEGA 6. Jurnal Kesehatan Masyarakat Andalas, 7(1), 26-31.

Gani, L. A., Sirajudin, N., \& Ahmad, Z. (2013). Asosiasi dan Pola Sebaran Bulu Babi ( Echinoidea) di Pantai Maregam Kota Tidore Kepulauan. Jurnal Bioedukasi, 2(1), 171-179.

Ginting A. R., S. Sitorus dan W. Astuti. (2017). Penentuan Kadar Asam Amino Esensial (Metionin, Leusin, Isoleusin dan Lisin) pada Telur Penyu dan Telur Bebek. Jurnal Kimia Mulawarman, 14(2), 91-99.

Hadinoto, S., Sukaryono, I. D., \& Siahay, Y. (2017). Kandungan Gizi Gonad dan Aktivitas Antibakteri Ekstrak Cangkang Bulu Babi (Diadema setosum). Jurnal Pascapanen dan Bioteknologi Kelautan dan Perikanan, 12(1), 71-78.
Hardinsyah, H. Riyadi dan V. Napitupulu. (2016). Kecukupan Energi, Protein, Lemak dan Karbohidrat. HIm 1-26.

Hasi, M. S., Lumingas, L. J. L. dan Lohoo, A. V. (2016). Analisis Allometri dan Indeks Fisiologis Bulu Babi Heliocidaris crassipina (A. Agassiz, 1864) (Camarodonta, Echinometridae) di Rataan Terumbu Tongkeina dan Malayang Dua, Manado, Sulawesi Utara. Jurnal IImiah Platax, 4(2). UNSRAT. Sulawesi.

Hickman, C., S. Larry., L. Susan., I. Helen., J. David. (2008). Integrated Principles of Zoology Fourteenth Edition. New York: McGraw-Hill Higher Education.

Huda, M. A. I., Sudarmadji, S., \& Fajariyah, S. (2017). Keanekaragaman Jenis Echinoidea di Zona Intertidal Pantai Jeding Taman Nasional Baluran. Berkala Sainstek, 5(2), 61-65.

Jati, D. K., \& Nindya, T. S. (2017). Asupan energi dan protein berhubungan dengan gizi kurang pada anak usia 6-24 bulan. Amerta Nutrition, 1(2), 124-132.

Jaziri A. A., Sukoso dan M. Firdaus. (2017). Karakteristik Protease dari Ekstrak Kasar Khamir Laut dan Aktivitasnya dalam Menghidrolisis Protein Ikan Rucah. Journal of Fisheries and Marine Science, 1(2), 78-87.

Kessel, A. and Ben-tal, N. (2010). Introduction to Proteins: Structure, Function, Motion. CRC Press. France.

Laposata, M. (1995). Fatty acids: biochemistry to clinical significance. American journal of clinical pathology, 104(2), 172-179.

Leba, M. A. U. (2017). Ekstraksi dan Real Kromatografi. Yogyakarta. Deepublish.

Lubis, S. A., Purnama, A. A., \& Yolanda, R. (2017). Spesies Bulu Babi (Echinoidea) Di Perairan Pulau Panjang Kabupaten Bangka Tengah Provinsi Bangka Belitung. Jurnal IImiah Mahasiswa FKIP Prodi Biologi, 3(1).

Muchtadi, T. R. dan Sugiyono. (1992). IImu Pengetahuan Bahan Pangan. Bogor. Institut Pertanian Bogor

Murray, R. K., Granner, D. K., Mayes, P. A. and Rodwell, V. W. (2003). Harper's Illustrated Biochemistry. Lange Medical Book. Medical Publishing Division. London.

Panagan, A. T., Yohandini, H., \& Gultom, J. U. (2011). Analisis kualitatif dan kuantitatif asam lemak tak jenuh omega-3 dari minyak ikan patin (Pangasius pangasius) dengan metoda kromatografi 
gas. Jurnal Penelitian Sains, 14(4), 3842.

Paransa, D. S., Kemer, K., Rumengan, A. P., \& Mantiri, D. M. (2014). Analisis jenis pigmen dan uji aktivitas antibakteri ekstrak pigmen xantofil pada alga coklat sargassum polycystum (c. agardh). Jurnal LPPM Bidang Sains dan Teknologi, 1(1), 90-96.

Pringgenies, D. Ana, A. Indriatmoko, Sri, S. dan Dwi, H. (2016). The Potency of Sea Urchin (Diadema setosum) Gonad on Brain Cell of White Rats (Rattus norvegicus). Asian Journal of Pharmaceutics, 10(2), 100-107.

Pringgenies, D. Yoram, W. dan Ridho, A. (2012). Perilaku Seksual dan Kadar Testosteron Darah Tikus Putih (Rattus norvegicus) Strain Wistar Akibat Pemberian Pakan Gonad Bulu Babi (Diadema setosum). Prosiding I Seminar Nasional Bioteknologi Kelautan dan Perikanan 2012. Vol. 1. Universitas Diponegoro. Semarang.

Purnami, S. E., \& Pratiwi, R. T. (2014). Profil Asam Lemak Gonad Lima Spesies Landak Laut (Echinoidea) Dari Pantai Selatan Kabupaten Gunung Kidul Daerah Istimewa Yogyakarta. Biota: Jurnal IImiah IImu-IImu Hayati, 19(1), 914.

Purwaningsih, S. (2012). Aktivitas Antioksidan dan Komposisi Kimia Keong Matah Merah (Cerithidea obtusa)(Antioxidant Activity and Nutrient Composition of Matah Merah Snail (Cerithidea obtusa)). IImu Kelautan: Indonesian Journal of Marine Sciences, 17(1), 39-48.

Purwaningsih, S., Salamah, E., \& Apriyana, G. P. (2013). Profil protein dan asam amino keong ipong-ipong (Fasciolaria salmo) pada pengolahan yang berbeda. Jurnal Gizi dan Pangan, 8(1), 77-82.

Rahayu, M., \& Yulianto, T. (2014). Profil Asam Amino Yang Terdistribusi Ke Dalam Kolom Air Laut Pada Ikan Kembung (Rastrelliger Kanagurta) Sebagai Umpan (Skala Laboratorium). Journal of Fisheries Resources Utilization Management and Technology, 3(3), 238-247.

Rahman, M. A., Arshad, A., \& Yusoff, F. M. (2014, July). Sea urchins (Echinodermata: Echinoidea): Their biology, culture and bioactive compounds. In International Conference on Agricultural, Ecological and Medical Sciences. Retrieved from http://iicbe. org/upload/8432C714075. pdf.
Rosaini, H., Rasyid, R., \& Hagramida, V. (2017). Penetapan kadar protein secara kjeldahl beberapa makanan olahan kerang remis (corbiculla moltkiana prime.) dari Danau Singkarak. Jurnal Farmasi Higea, 7(2), 120-127.

Rubiyanto, D. (2013). Teknik Dasar Kromatografi-Ed.1. Deepublish. Yogyakarta. Hal. 65.

Rustamaji, E. (2012). Penggunaan GPS untuk Memetakan Sebaran dan Pemilihan Sekolah Dasar Negeri di Propinsi Bali. Studia Informatika: Jurnal Sistem Informasi, 5(2), 1-7.

Sartika, R. A. D. (2008). Pengaruh asam lemak jenuh, tidak jenuh dan asam lemak trans terhadap kesehatan. Kesmas: National Public Health Journal, 2(4), 154-160.

Satria, R. G. D., Sumiarto, B., Trisyono, A., \& Wijayanti, D. (2014). Pengoptimalan Metode Kromatografi Cair Kinerja Tinggi dalam Analisis Senyawa Deltamethrin sebagai Residu dalam Produk Asal Hewan. Jurnal Kedokteran HewanIndonesian Journal of Veterinary Sciences, 8(1), 68-71.

Schultz., A. G. Heinke. (2015). Handbook of Zoologi. Berlin: Heinke \& Peter Schultz Scientific Publication.

Silaban, B. B. dan Srimarina, E. S. (2013). Kandungan Nutrisi dan Pemanfaatan Gonad Bulu Babi (Echinotrixs calamaris) dalam Pembuatan Kue Blunder. JPHPI, 16(2), 108-118.

Subandiyono dan Hastuti, S. (2016). Buku Ajar Nutrisi Ikan. Lembaga Pengembangan dan Penjaminan Mutu Pendidikan. Universitas Diponegoro. Semarang.

Sugiyono. (2004). Kimia Pangan. Universitas Negeri Yogyakarta.

Sumardjo, D. (2008). Pengantar Kimia: Buku Panduan Kuliah Mahasiswa Kedokteran dan Program Strata I Fakultas Bioeksata. Buku Kedokteran EGC, Jakarta, hal.23, 161.

Sumardjo, D. (2009). Pengantar Kimia. Buku Panduan Kuliah Mahasiswa Kedokteran dan Program Strata I Fakultas Bioeksakta. Penerbit Buku Kedokteran EGC: Jakarta. Hal. 161-172.

Suryabrata, S. (2016). Metodologi Penelitian. Jakarta: Rajawali Pers.

Suryanti, S., \& Ruswahyuni, R. (2014). Perbedaan Kelimpahan Bulu Babi (Echinoidea) pada Ekosistem Karang dan Lamun di Pancuran Belakang, Karimunjawa, Jepara. Jurnal Saintek Perikanan, 10(1), 63-67. 
Susanti, M. Dan Dachriyanus. (2017). Kromatografi Cair Kinerja Tinggi. Lembaga Pengembangan Teknologi Informasi dan Komunikasi (LPTIK) Universitas Andalas. Sumatera Barat. $92 \mathrm{hlm}$.

Talumepa, A. C., Suptijah, P., Wullur, S., \& Rumengan, I. F. (2016). Kandungan kimia dari sisik beberapa jenis ikan laut. Jurnal LPPM Bidang Sains dan Teknologi, 3(1), 27-33.

Toha, A. H. A. (2006). Manfaat bulu babi (Echinoidea), dari sumber pangan sampai organisme hias. Jurnal IImu-IImu Perairan dan Perikanan Indonesia, 13(1), 77-82.

Tupan, J., \& br Silaban, B. (2017). Karakteristik Fisik-Kimia Bulu babi Diadema setosum dari beberapa Perairan Pulau Ambon. TRITON: Jurnal Manajemen Sumberdaya Perairan, 13(2), 71-78.

Ulya N., P. M. Ratna, S. Artanti, D. Kusumawardhani dan U. Sa'adah. (2015). Faktor-faktor yang Berhubungan dengan Konsumsi Ikan pada Anak Usia 1-3 Tahun di Kota Pekalongan. Jurnal Litbang Kota Pekalongan, 8, 32-42.

Umagap, W. A. (2013). Keragaman Spesies Landak Laut (Echinoidea) Filum Echinodermata Berdasar Morfologi Di Perairan Dofa Kabupaten Kepulauan Sula. Jurnal Bioedukasi, Ternate, 1(2), 94-100.

Utami, P., Lestari, S., \& Lestari, S. D. (2016). Pengaruh metode pemasakan terhadap komposisi kimia dan asam amino ikan seluang (Rasbora argyrotaenia). Jurnal FishtecH, 5(1), 73-84.

Wijayanti, I. E. (2017). Analisis Asam Amino pada Minyak Kelapa dengan Proses Pengasaman Menggunakan HPLC. EduChemia (Jurnal Kimia dan Pendidikan), 2(1), 40-51.

Wina, E., \& Susana, I. W. R. (2013). Manfaat lemak terproteksi untuk meningkatkan produksi dan reproduksi ternak ruminansia. Wartazoa, 23(4), 176-184.

Zakaria, I. J. (2013). Komunitas Bulu Babi (Echonoidea) di Pulau Cingkuak, Pulau Sikuai dan Pulau Setan Sumatera Barat. Prosiding SEMIRATA 2013, 1(1). 